\title{
RIASAN WAJAH SEBAGAI BAGIAN GAMBAR DIRI
}

\section{Bukan Sekadar Kewajiban atau Hasrat}

\author{
Irene Chrysantheme Roan Pea \\ Gereja Kristen Indonesia \\ irenechroanpea@gmail.com
}

\begin{abstract}
This paper discusses the image of the human body as an important existential component amid the totality of existence in its sociocommunal construction. Body image is itself constructed upon one's impressions, thoughts, feelings, and opinions about one's own body. In light of the proliferation of beauty vlogger accounts on various social media platforms (YouTube and Instagram) demonstrating various makeup techniques for women, the author sets forth a reconstructive critique [kritik rekonstruksi] against the hustle-and-bustle of modernism that traps humanity within the assemblage of an industrialist-colonialist gaze that proclaimes makeup (facial cosmetics) to be constitutive for humanity's selfimage, particularly impacting women. The author argues that human persons are, in truth, creatures of beauty and worth in the authenticity of their self-image even without the aide of makeup, by considering the concept of 'body image' within the realm of psychology in addition to the theological aesthetic perspective of Hans Urs von Balthasar.
\end{abstract}

Keywords: theological aesthetics, beauty [keindahan], makeup, selfimage [gambar diri], Gestalt, Balthasar, existence, beauty [attractiveness], fragility, desire, self-image [citra tubuh], relativity

Abstrak
Tulisan ini berbicara tentang citra tubuh manusia sebagai bagian
penting dari totalitas eksistensi di dalam konstruksi sosial-
masyarakat. Citra tubuh sendiri terbangun berdasarkan kesan,
pikiran, perasaan, dan opini seseorang tentang tubuhnya. Terkait
dengan maraknya beauty vlogger pada berbagai akun media sosial
(YouTube dan Instagram) yang mendemonstrasikan berbagai teknik
makeup bagi perempuan, penulis mengemukakan kritik
rekonstruksi terhadap hiruk-pikuk modernisme yang


menempatkan manusia terjebak dalam konstruksi pandangan industri-kolonialisme yang mengatakan bahwa tata rias wajah (makeup) menjadi bagian dari gambar diri manusia, khususnya bagi perempuan. Penulis berargumentasi bahwa manusia sejatinya adalah mahluk yang indah dan berharga dalam keaslian gambaran dirinya meski tanpa bantuan tata rias wajah dengan menggunakan konsep body image dalam ranah psikologi dan sudut pandang estetika dari Hans Urs von Balthasar.

Kata-kata Kunci: theological aesthetic, keindahan, makeup, gambar diri, Gestalt, von Balthasar, eksistensi, kecantikan, kerapuhan, hasrat, citra tubuh, relativitas

\section{Pendahuluan}

Riasan wajah bukan merupakan hal yang baru bagi manusia. Secara khusus bagi perempuan, tata rias wajah menjadi bagian yang tidak terpisahkan dari kehidupan sehari-hari karena dianggap mampu menambah kecantikan diri secara fisik. Dalam melakukan tindakan merias wajah, bahan yang digunakan disebut sebagai kosmetik, sedangkan ilmu mengenai tata cara mempercantik diri disebut kosmetika. ${ }^{1}$

Berdasarkan sejarah perkembangannya, bahan-bahan kosmetik yang dipakai dalam usaha untuk mempercantik diri, pada dahulu kala diramu dari bahan-bahan alami yang terdapat di sekitar dan pengolahannya pun bersifat konvensional tanpa bahan kimia sebagai pengawet. Saat ini kosmetik tidak hanya terbuat dari bahan alami tetapi juga bahan buatan untuk maksud meningkatkan kecantikan. ${ }^{2}$ Bahan buatan inilah yang seringkali dapat menimbulkan berbagai efek negatif yang dapat merusak kulit wajah dan bahkan tubuh. ${ }^{3}$ Meskipun demikian, penggunaan kosmetik sebagai tata rias tidak ditinggalkan begitu saja melainkan justru semakin diminati karena dianggap dapat membantu mempercantik secara instan. Selain itu, kosmetika menjadi ilmu yang dicari dan disebarkan baik itu dalam bentuk seminar (beauty class), media cetak

${ }^{1}$ Istilah kosmetika sendiri berasal dari bahasa Yunani yaitu Kosmetikos yang berarti keahlian dalam menghias. Retno Iswari Tranggono menyatakan kosmetik tidak hanya memberikan dampak kecantikan bagi penggunanya melainkan juga kesehatan bagi tubuh. Pada abad ke-19, pemakaian kosmetik mulai mendapat perhatian, yaitu selain untuk kecantikan juga untuk kesehatan. Namun perkembangan ilmu kosmetika serta industrinya baru dimulai secara besar-besaran pada abad ke-20. Cara pandang yang lebih lengkap dapat dilihat pada Retno Iswari Tranggono dan Fatma Latifah, Buku Pegangan Ilmu Pengetabuan Kosmetik, ed., Joshita Djajadisastra (Jakarta: Gramedia, 2007), 3. Press, 1997), 4.

2 Sjarif M. Wasitaatmadja, Penuntun Ilmu Kosmetik Medik (Depok: UI

3 Tranggono dan Latifah, Buku Pegangan Ilmu Pengetahuan Kosmetik, 43. 
maupun media digital seperti yang lazim ditemukan pada berbagai tayangan YouTube dan fitur stories pada aplikasi Instagram.

Fenomena maraknya ragam teknik kosmetika ini kemudian menimbulkan suatu pertanyaan sekaligus sebuah pernyataan bahwa tata rias wajah kini menjadi bagian dari kehidupan harian manusia. Pertanyaan saya untuk membuka tulisan ini adalah "Ada apa dibalik tata rias wajah (kosmetik) sehingga sifat kehadirannya tidak lagi tersier melainkan sekunder dan bahkan primer bagi sebagian besar wanita bahkan remaja putri berumur belasan tahun?" Pertanyaan ini saya ungkapkan sebagai bagian dari perumusan hipotesis bahwa kehadiran tata rias telah menjadi bagian dari jati diri perempuan, termasuk umat Kristen. Hipotesis ini menjadi penting karena pemahaman bahwa hakikat manusia terkait erat dengan penciptaan, yakni semua hal diciptakan Allah dengan unsur keindahan serta kebaikan di dalamnya. Di dalam pembahasan teologi Kristen, penciptaan merupakan bentuk penyataan Ilahi (Divine revelation). Allah, Sang Pencipta yang asali, murni dan penuh dengan segala rancangan pengetahuan, kebaikan, dan juga keindahan, telah mengetahui dan mengasihi serta turut berpartisipasi menikmati seluruh ciptaan-Nya. ${ }^{4}$ Realita penciptaan yang baik dan indah ini kemudian dianut oleh umat Kristen dan menjadi sebuah dogma tersendiri yang menggarisbawahi bahwa manusia adalah cerminan gambar dan rupa Allah. ${ }^{5}$

Dalam tulisan ini, saya menempatkan diri pada posisi pengamat sekaligus pengguna efek tata rias wajah (makeup) yang saya artikan sebagai seni. Namun sebelum membahas lebih jauh mengenai tata rias dan kecantikan, terlebih dahulu saya akan menelaah makna keindahan atau kecantikan bagi masyarakat modern. Kemudian, saya akan menggali definisi dan fungsi tata rias wajah bagi manusia, khususnya perempuan, yang terkait dengan realitas ketergantungan masyarakat modern terhadap kosmetika dan tata rias wajah. Oleh sebab itu, selanjutnya akan disajikan berbagai pemikiran atau pendapat mengenai makna tata rias wajah yang seolah menjadi bagian dari jati diri serta pemenuhan kepuasan pribadi manusia terhadap dirinya. Dalam melakukan telaah dan rekonstruksi pemikiran manusia mengenai keindahan (estetika) dan tindakan merias wajah (makeup), saya menggunakan konsep body image dalam ranah filsafat, teologi, serta psikologi dari berbagai tokoh, serta sudut pandang estetika menurut Hans Urs von Balthasar. Tujuan akhir tulisan ini adalah memperlihatkan bahwa tata rias (kosmetik) dan kosmetika adalah seni pelengkap, dan bukan wajib, bagi manusia untuk melihat dirinya sebagai gambaran yang utuh. Saya juga berargumentasi bahwa tindak-laku dalam

\footnotetext{
${ }^{4}$ John Navone, Toward a Theology of Beauty (Collegeville, MN: Liturgical Press, 1996), 1.

${ }^{5}$ Ibid., 12-13.
} 
memperlakukan tubuh sebagai manusia akan mencerminkan otentisitas pribadi.

\section{Tata Rias Wajah:}

\section{Seni, Apresiasi dan Media Eksistensi Diri Manusia}

Sebelum masuk pada analisis mengenai hakikat diri manusia-yang kemudian akan difokuskan pada remaja putri dan wanita dewasa muda-saya terlebih dahulu akan memperhatikan tujuan dan fungsi kosmetika atau tata rias wajah. Tata rias wajah merupakan unsur pelengkap di dalam keseharian manusia. Tata rias menurut sejarahnya digunakan pada pertunjukan teater, siaran televisi, dan lakon film. Namun jika dilihat dari segi estetisnya, tata rias wajah merupakan seni mengaplikasikan bahan-bahan kosmetika (kosmetikos) pada wajah seseorang sebagai alat bantu memantapkan lakon tertentu. Tata rias adalah suatu ilmu yang mempelajari tentang seni mempercantik diri sendiri atau orang lain dengan bantuan efek kosmetika. Menurut Penny Delamar sebagai ahli tata rias, komponen materi pada setiap tindakan merias wajah, mungkin sama tetapi harus diperhatikan bahwa teknik dan efeknya berbeda-beda. ${ }^{6}$ Saya merasa ada baiknya kita mengetahui fungsi penerapan tata rias wajah dalam pengaplikasiannya pada kehidupan sehari-hari. Dalam bidang tata rias wajah, terdapat tiga jenis fungsi penerapan tata rias wajah. Jenis yang pertama yaitu tata rias korektif, tata rias fantasi dan tata rias karakter.

Tata rias korektif adalah tata rias wajah yang bersifat menyempurnakan dan mengubah penampilan fisik yang dipandang tidak sempurna. Tata rias wajah korektif merupakan jenis tata rias wajah yang lazim digunakan. Sedangkan tata rias wajah fantasi adalah jenis tata rias yang bertujuan untuk membentuk kesan wajah subjek yang dirias menjadi wujud khayalan yang diangan-angankan seperti wajah hewan tertentu atau tumbuhan. Jenis yang ketiga adalah tata rias wajah karakter yang mengubah penampilan wajah seseorang dalam hal umur, bangsa, sifat dan ciri-ciri khusus yang melekat pada tokoh tertentu seperti tokoh nenek-nenek atau tokoh pak Raden dalam lakon Unyil. ${ }^{7}$ Jenis kedua dan ketiga ini paling sering digunakan untuk pementasan lakon dan drama pada televisi dan teater. Sedangkan jenis pertama menjadi perbincangan hangat dan topik utama tulisan ini yaitu dilakukan sehari-hari untuk menutupi berbagai kekurangan yang dirasakan nampak oleh pemakainya.

Bagi Delamar, pengguna tata rias atau makeup harus memahami anatomi wajah dan mengetahui dengan jelas tujuan

${ }^{6}$ Penny Delamar, The Complete Make-up Artist: Working in Film, Television \& Theatre (London: Macmillan, 1995), 1.

7 Ibid., 13-14. 
dirinya merias wajah. ${ }^{8}$ Pada umumnya tata rias wajah jenis pertama (koreksi) dianggap mampu berfungsi untuk mengatasi kelemahan wajah. Kelemahan yang dimaksud antara lain adalah penuaan dini (aging) yang ditandai dengan kelopak mata yang berkerut, garis senyum yang semakin jelas dan daerah bawah mata yang terlalu dalam atau menghitam. ${ }^{9}$ Kelemahan yang disebutkan di atas bukan bermaksud mengatakan bahwa terdapat kerusakan melainkan lebih mengarah pada analogi terhadap penghargaan diri yang menurun akibat pertambahan usia. Koreksi pada wajah pada dasarnya dimaksudkan para pengguna tata rias koreksi, sebagai media yang menutupi kekurangan dan mengembalikan kepercayaan diri mereka. ${ }^{10}$ Selain itu, ketika memperhatikan realita di berbagai negara dan kota besar, tata rias wajah bagi sebagian perempuan matang (secara usia)—yang memang berada pada rutinitas perkantoran (selanjutnya disebut wanita karier)—dapat dijawab dengan dalih sebagai tuntutan karir. Namun sayangnya-seperti yang saya telah bahas pada bagian pendahuluan - tren penggunaan kosmetik nampaknya tidak hanya menjangkiti para pekerja seni ataupun wanita karir tetapi juga remaja dan bahkan pada anak-anak sehingga habituasi ini pun dilakukan oleh mereka di dalam lingkungan sekolah. ${ }^{11}$ Mengapa hal ini terjadi dan apa saja dampaknya bagi fisik dan spiritualitas?

Demi tujuan mengkontekstualisasi definisi kecantikan atau keindahan di masa kini, saya mencoba mencari definisi beauty melalui wawancarakepada tujuh orang yang berusia dimulai dari 1633 tahun. ${ }^{12}$ Tujuh orang tersebut saya sebut sebagai perwakilan kelompok lelaki dan perempuan. Tiga orang perempuan dan empat orang lelaki ini menyatakan pendapat mereka mengenai definisi kecantikan. Dalam proses wawancara, saya memberikan satu pertanyaan yaitu "Bagaimanakah ukuran cantik atau indah menurutmu?" Jawaban atas pertanyaan tersebut beragam. Lima dari tujuh orang menyatakan dengan tegas bahwa cantik atau indah adalah relativitas cara pandang yang terkait dengan kealamian, sementara dua lainnya mengemukakan definisi rinci atau tepatnya

8 Ibid., 1-2.

9 Aju Isni Karim dan Andiyanto, The Make Over: Rahasia Rias Wajah Sempurna (Jakarta: Gramedia, 2005), 30.

10 Ibid., 32.

11 Pengamatan pada berbagai unggahan dari akun media sosial milik anak dan remaja dan artikel mengenai pola perilaku remaja yang membawa atau mengenakan tata rias wajah di sekolah. Selengkapnya, lih. Ririn Indriani dan Firsta Nodia, "Banyak Remaja Pakai 'Makeup' ke Sekolah, Apa Kata Psikolog?," Suara, 16 Agusus, 2017, diakses 4 Juli 2020, https://www.suara.com/lifestyle/2017/08/16/130000/banyak-remaja-pakaimakeup-ke-sekolah-apa-kata-psikolog.

12 Yosef Desdian (22), Hendra Sirait (33), Marvel Manalu (23), Kevin Jonatan (25), Haiti Maria (23), Adinda Lombu (17), Astari Irawan (27). Melalui wawancara tak berstruktur oleh penulis. Jakarta, Indonesia, April-Mei 2017. 
standar tertentu terhadap hal yang mereka sebut "cantik atau indah" (contoh: bulu mata lentik, putih, tinggi, dsb).

Melalui tujuh orang tersebut, saya membuat pengelompokan usia. Rupanya, yang menjawab bahwa cantik merupakan standar relatif yang dapat dilihat dari kealamian dalam diri (attitude) adalah mereka yang berusia 20 tahun ke atas. Sementara yang memiliki gambaran bahwa seseorang disebut cantik atau indah bila berkulit putih atau kuning langsat, berhidung mancung dan memiliki dagu tirus adalah mereka yang berusia 1619 tahun. Saya mencoba mengutip salah satu narasumber berjenis kelamin laki-laki berusia 30 tahunan:

Cantik itu relatif tapi terkait hal yang alami dan bukan buatan. Tercipta menurut cara pandang kamu secara pribadi. Tidak semua hal yang sama dipandang sebagai keindahan universal. Sebagai contoh, jika semua orang punya pemahaman yang sama bahwa satu lelaki atau perempuan itu ganteng atau cantik, pasti semua orang menginginkan dia. Misal lagi, kalo yang tinggi itu ganteng, pasti semua perempuan akan mengingini mereka yang tinggi. Menurut perspektif saya, cantik itu apa yang alami karena cantik itu terkait otentisitas. ${ }^{13}$

Berbeda pula dengan definisi dari Astari Irawan, seorang beauty vlogger (pembuat video tutorial tata rias wajah pada aplikasi YouTube) berusia 27 tahun, yang mengatakan bahwa kecantikan adalah hasil dari sebuah usaha perempuan dan lelaki untuk menampilkan diri secara maksimal:

Bukan karena gue seorang beauty vlogger, tapi standar hidup gue adalah kesempurnaan. Gue tinggal nomaden. Negara pindah-pindah. Gue liat dari yang tinggi sampe pendek. Hitam, sawo matang, kuning langsat sampai seputih mayat pun gue lihat. Mereka intinya cantik. Mereka ganteng. Tapi percuma kalo gak dirawat maksimal. Kalo gak ditampilin maksimal, ya buat apa? Percuma kalo pucet. Kalo pucet, apa istimewanya elo dari yang lain? Gue melihat semua cantik tapi kalo gak stunning, that's vain. That's why do we need a makeup for life. ${ }^{14}$

Bagi Astari, kecantikan memang menjadi identitas dasar manusia tetapi pancarannya harus diusahakan agar terlihat oleh orang lain. Hal tersebutlah yang melatarbelakangi dirinya menjadi

\footnotetext{
${ }^{13}$ Hendra Sirait, "Wawancara oleh Penulis" (Jakarta, Indonesia, 2017).

14 Astari Irawan, "Wawancara Oleh Penulis" (Purwakarta, Indonesia, 2017).
} 
pemakai tata rias wajah. ${ }^{15}$ Melalui penuturan-penuturan tersebut, saya menganalisis bahwa konstruksi pemikiran seseorang dalam menanggapi kecantikan atau keindahan, berasal dari pengalamannya menjalani kehidupan. Seperti pernyataan von Balthasar, kerangka idealisme seseorang menanggapi bentuk kecantikan adalah hasil dari pengalaman yang direfleksikan dalam paradigma memandang identitas individu lainnya. ${ }^{16}$ Akibatnya, identitas manusia jika dipandang oleh setiap individu menjadi relatif. Namun, tetap dalam hakikatnya sering terkandung unsur hasrat untuk bereksistensi.

Hasrat untuk bereksistensi inilah yang akhirnya cenderung bersifat destruktif jika tidak dapat dikelola dengan baik, sebab hasrat mampu menarik manusia pada kondisi mudah terluka. Hipotesis ini didukung oleh teori Kristine Culp mengenai buman vulnerability. Culp mengatakan bahwa manusia cenderung melukai dan terlukai ketika menjalani kehidupan. Dalam memandang suatu peristiwa, manusia telah menganut pandangan lokal yang menjadi standar memberi penilaian atau tanggapan. Masyarakat global pada abad ke-20 mulai terarah dan terdidik untuk memandang segala sesuatu berdasarkan kombinasi nalar dan nurani. Namun, kombinasi antara nalar dan nurani tersebut, membiasakan manusia untuk bersikap saling mencurigai dan menyakiti sesamanya. ${ }^{17}$ Pada akhirnya manusia menciptakan derita bagi dirinya sendiri dan mudah terluka melalui berbagai konstruksi pemikiran yang berlaku di tengah masyarakat - termasuk mengenai definisi keindahan dan kecantikan terkait mereka yang melakukan tata rias pada dirinyasehingga tak ayal menjalani gaya hidup (lifestyle) yang dikontrol oleh tren tertentu. Lalu pertanyaan yang timbul "Apa faedah dari berhias wajah dan memberlakukan teknik kosmetika dalam kehidupan sehari-hari? Pertanyaan selanjutnya terkhusus bagi umat Kristiani adalah "Allah menciptakan manusia dalam keadaan baik dan segambar dengan citra diri-Nya, lalu perlukah kosmetik untuk memperindah wajah?

\section{Remaja (Perempuan) Ber-makeup}

Menurut survei yang dilakukan oleh tim Kementrian Perindustrian Indonesia (KEMENPERIN), Industri kosmetik nasional mencatatkan kenaikan pertumbuhan 20\% atau empat kali lipat dari pertumbuhan ekonomi nasional pada tahun 2017. Dikutip dari website KEMENPERIN, Menteri Perindustrian RI Airlangga Hartanto mengatakan bahwa Indonesia merupakan salah satu

15 Ibid.

16 Oliver Davies, "The Theological Aesthetics," in The Cambridge Companion to Hans Urs von Balthasar, eds., Edward T. Oakes and David Moses (Cambridge: Cambridge University Press, 2004), 132-133.

17 Kristine A. Culp, Vulnerability and Glory: A Theological Account (Louisville, KY: Westminster John Knox Press, 2010), 117-118. 
target pasar kosmetik disebabkan permintaan yang cukup tinggi dari penggunanya terhadap kosmetik. ${ }^{18}$ Saat ini, produk kosmetik sudah menjadi kebutuhan primer bagi kaum wanita bahkan pria dan anak-anak. Akibatnya, industri kosmetik di dalam negeri bertambah sebanyak 153 perusahaan pada tahun 2017, dan, hingga saat ini, jumlah keseluruhannya mencapai lebih dari 760 perusahaan. Pada bagian ini, saya akan membahas secara khusus mengenai penggunaan kosmetik (makeup) pada remaja perempuan.

Masa remaja dikenal sebagai masa yang penuh dengan kesukaran karena banyak tingkah perilaku remaja yang sulit untuk dipahami oleh dirinya, orang tua, pendidik dan masyarakat. Hal ini disebabkan masa remaja adalah masa transisi antara masa kanakkanak dan masa dewasa. Masa transisi ini memperhadapkan remaja pada realita bahwa dirinya bukan sepenuhnya kanak-kanak tetapi juga belum dewasa tetapi harus belajar bersikap dan berpikir visioner layaknya orang dewasa. ${ }^{19}$ Situasi ini jelas menimbulkan konflik bagi diri remaja yang sedang mencari identitas diri sehingga mendorongnya mencoba melakukan banyak hal yang dilakukan oleh orang dewasa, termasuk menekuni tata rias wajah.

Berdasarkan hasil pengamatan-baik pustaka maupun lapangan-dapat saya katakan bahwa perilaku remaja masa kini (generasi Y akhir dan Z) dapat dikategorikan sebagai remaja yang rentan karena mudah mendapatkan informasi sekaligus dihinggapi oleh ketidakmatangan emosional. ${ }^{20}$ Dalam hal ini dapat dikatakan bahwa remaja sedang berada di dalam suasana serba bingung yang mendorong diri mereka untuk membebaskan diri dari berbagai keterikatan peraturan atau stigma. Oleh sebab itu, mereka berusaha mencari sebuah pengakuan terhadap eksistensi diri mereka-di dalam lingkungan sosial masyarakat-sesuai ekspektasi masingmasing yang mereka kembangkan dari model berpikir atau tindakan tertentu. Salah satunya adalah usaha untuk diakui oleh lingkungan bahwa kondisi fisik mereka termasuk dalam kriteria ideal (seturut role model tertentu).

Seiring tumbuh kembang menuju fase dewasa muda, remaja yang tengah berproses dalam pembentukan identitas diri membutuhkan model untuk ditiru dan selanjutnya mengidentifikasikan dirinya dalam peran tokoh yang sedang diamati atau diidolakan. Alasan kebutuhan ini didorong oleh keinginan besar untuk diterima oleh kelompok atau lingkungan

18 Gora Kunjana, "Industri Kosmetik Nasional Tumbuh 20\%," 2018, Investor, diakses 4 Juli 2020, https://investor.id/archive/industri-kosmetiknasional-tumbuh-20. 2012), 72 .

${ }^{19}$ Sarlito W. Sarwono, Pengantar Psikologi Umum (Jakarta: Rajawali Press,

${ }^{20}$ John Janeway Conger and Nancy L. Galambos, Adolescence and Youth: Psychological Development in a Changing World (New York: Addison-Wesley Educational Publisher, 1997), 22. 
tertentu yang mereka anggap akan mengokohkan identitas diri yang sedang dibangun. ${ }^{21}$ Untuk melengkapi proses imitasi tersebut, remaja masa kini tidak segan untuk melakukan berbagai usaha seperti mengadopsi persepsi, gaya berpakaian bahkan gaya merias diri dan wajah. Tidak dapat dipungkiri, remaja masa kini-yang sedang mencari identitas diri-akan mencoba berbagai teknik merias wajah meski hal tersebut tidak selalu diperlukan. Saya katakan tidak selalu diperlukan sebab, mengacu pada ketiga definisi dan fungsi tata rias wajah yang telah saya paparkan di atas, sejatinya tata rias wajah hanya digunakan untuk pementasan lakon atau pun menutupi bagian-bagian tidak sempurna dari wajah (acne, scar, aging). Dalam hal ini remaja tidak perlu menutupi apapun dengan tata rias wajah terlebih jika digunakan di dalam lingkungan sekolah. Sayangnya, penggunaan tata rias ini kemudian dapat menjadi suatu hobi, bahkan ketergantungan, yang melatenkan penggunaan tata rias wajah di segala kesempatan dan tempat. Tata rias wajah yang semula difungsikan sebagai bagian tersier kehidupan manusia, kini bergeser fungsi menjadi kebutuhan primer hingga mengaburkan definisi manusia yang baik dan cantik (indah) keadaannya dalam gambar dan rupa Allah. Ketika tata rias wajah menjadi sebuah ketergantungan untuk fungsi korektif, maka secara tidak langsung pemakainya-baik berusia remaja dan terbawa hingga dewasatelah menempatkan dirinya pada pemahaman diri tidak lengkap dan membutuhkan perbaikan. Pemakainya kehilangan makna akan gambar dirinya yang baik di mata Allah dan berhasrat mengubah dirinya menjadi citra yang lain.

Hal yang saya maksudkan sebagai pengubahan diri menjadi citra yang lain adalah termasuk keinginan untuk menampilkan diri mengimitasi dengan mengubah tampilan secara fisik menyerupai tokoh atau model tertentu. Sebagai contoh, beberapa tahun ini, fenomena Korean wave tengah kuat memengaruhi pola pikir masyarakat, khususnya remaja perempuan hingga wanita dewasa muda, dalam hal menata tampilan diri. Tersebarnya budaya pop Korea secara global membuat berbagai produk kosmetik dan skin care semakin laris, khususnya produk-produk Korea. Menurut CEO Ra Beauty Core, Kim Hyun Tae, bahwa kemalasan merupakan faktor kunci yang membuat industri kecantikan Korea terus berkembang. Berbagai produk kecantikan Korea seperti blemish balm (BB) cream, color control (CC) cream dan cushion foundation yang diciptakan untuk mempercepat proses aplikasi makeup, telah membuat mereka yang malas merawat diri secara telaten tetap memenuhi keinginannya untuk terlihat cantik. ${ }^{22}$

21 Ibid., 40-44.

22 Hestianingsih, "Tren Kecantikan Korea Populer karena Banyak Wanita Malas Pakai Makeup," 10 Oktober 2016, Detik, diakses 4 Juli 2020, https://wolipop.detik.com/read/2016/10/10/161049/3317070/\%0A234/tre n-kecantikan-korea-populer-karena-banyak-wanita-malas-pakai-makeup. 
Telah dipaparkan di dalam rubrik website Human Diseases and Conditions Forum bahwa citra diri atau gambaran diri manusia mengenai tubuh mereka mulai terbangun sejak masa remaja. Manusia menemukan identitas diri dimulai dari masa kanak-kanak. Kemudian pada masa remaja, mereka mulai membangun seperempat dari identitasnya. Hal yang dikatakan sebagai seperempat identitas adalah bagian demi bagian pengenalan akan diri individu yang tengah dijalani dalam keseluruhan rentang kehidupannya sebagai manusia.

Namun dalam proses tersebut, remaja sangat rentan terhadap kritik, godaan, atau komentar negatif. Baik anak laki-laki maupun perempuan mengalami lonjakan pertumbuhan dan perkembangan seksual yang membutuhkan pemaknaan dari dalam dan luar diri. Ciri diri remaja yang dipengaruhi oleh perubahan hormon bisa menyebabkan berbagai masalah bagi penampilan mereka, sehingga nampaknya dibutuhkan suatu adaptasi (pembiasaan diri) dengan citra baru mereka. ${ }^{23}$ Sayangnya tidak sedikit remaja yang dalam masa adaptasinya mengalami fase kehilangan kepercayaan diri akan penampilan mereka ketika menerima komentar negatif. Ketika komentar negatif telah menjatuhkan mereka (remaja) maka individu tersebut membawa sebuah luka bahwa mereka adalah "gambaran yang tidak sempurna" hingga ke masa dewasanya.

Oleh sebab pentingnya citra diri bagi seorang individu, maka berkembanglah pemikiran dalam lingkup masyarakat umum bahkan global, bahwasanya penampakan secara fisik menjadi tolok ukur kehidupan yang sangat penting. Penampakan secara fisik ini terkait dengan pengelolaan terhadap tubuh secara keseluruhan. Sayangnya, pemikiran yang saya paparkan tadi pun tidak terkecuali dimiliki oleh umat KristianiWajah yang merupakan bagian dari citra sebuah tubuh, kemudian menjadi salah satu simbol estetis yang terbuka dan melukiskan keindahan. Masalahnya adalah setiap manusia mencari sebuah standar kepuasan dan menciptakan berbagai poin standar kebutuhan yang beragam mengenai keindahan fisik (wajah). Oleh sebab itu, timbul hipotesa bahwa konsep gambar dan rupa Allah yang senantiasa digemakan di dalam Teologi Kristen nampak tidak lagi menjawab kepuasan diri individu-individu pencipta dan pecinta rekonstruksi atas standar keindahan fisik, terkhusus wajah. Maka tidak menjadi sebuah hal yang heran lagi apabila saat ini marak berbagai ide menyiasati kekurangan diri. Ide-ide tersebut hadir dalam bentuk inovasi hasil riset manusia demi menjawab pergolakan nalar dan kehausan akan pemenuhan diri melalui metode make up atau bahkan rekonstruksi

\footnotetext{
${ }^{23}$ Human Diseases and Conditions Forum, "Body Image," diakses 4 Juli 2020, http://www.humanillnesses.com/Behavioral-Health-A-Br/BodyImage.html.
} 
wajah. Alasannya adalah demi menjembatani idealisme atas konstruksi pemikiran global dalam menanggulangi pemikiran individu atas rasa rendah diri terhadap paras pribadi per-individu, yang tidak mampu terhindarkan.

\section{Manusia: Cantik Serupa dengan Allah}

Dalam bagian ini saya mengajak pembaca sekalian untuk sejenak mengingat kembali mengenai hakikat manusia yang diciptakan serupa dengan Allah. Sebagian besar umat Kristiani rasanya cukup akrab dengan konsep tersebut sejak mengenal kisah penciptaan dunia oleh Allah yang tercantum di dalam Alkitab. Dengan mengacu pada Kejadian 1:26, konsep tersebut menyatakan bahwa manusia tercipta menurut gambar dan rupa Allah. Dapat ditafsirkan, menurut bahasa asli ayat tersebut, bahwa Allah menciptakan manusia dalam keadaan istimewa. Allah memberi manusia sebuah keistimewaan dibandingkan mahluk ciptaan lain dalam ranah kemampuan berpikir mengelola kehidupan dan dalam memanfaatkan sumberdaya yang Allah berikan kepada manusia pertama (Adam dan Hawa) dan kemudian kepada kita. ${ }^{24}$

Dengan bahasa Kitab Kejadian yang dipenuhi narasi dengan unsur puisi, liturgi, dan sabda proklamasi, Allah digambarkan mencipta manusia dalam pertimbangan dan kesadaran yang penuh terhadap akan rencana-Nya mencipta manusia pertama hingga keturunannya. Secara garis besar dapat dikatakan bahwa kondisi penciptaan ini baik dan istimewa, sebab Allah menempatkan manusia dalam kondisi kesadaran terhadap realitas keberadaan dirinya sebagai ciptaan (manusia) yang utuh terencana dan termodelisasi penuh. ${ }^{25}$

Namun, dapat pula dikatakan bahwa predikat sangat baik yang diberikan Allah kepada setiap ciptaanNya, termasuk manusia, bukan merupakan jaminan terhadap kesempurnaan. Manusia sekarang ini dapat merayakan kreasi Allah yang sangat baik tetapi manusia pun tidak dapat menghindari realita bahwa kata "baik" merupakan terjemahan yang dipakai dalam Alkitab untuk mendeskripsikan hasil ciptaan Allah secara keseluruhan (bukan hanya dalam konteks manusia pertama,saja).

Singkatnya, predikat "keadaan baik" dalam hal ini merupakan deskripsi bahwa Allah telah mencipta bumi dan segala isinya untuk saling memperlengkapi. Namun di dalam kondisi baik sekali pun, kekurangan di dalam diri setiap ciptaan tidak dapat dihindarkan. Kekurangan tersebut berlaku pula untuk manusia. ${ }^{26}$

${ }^{24}$ Warren W. Wiersbe, The Wiersbe Bible Commentary (Colorado Springs, CO: David C. Cook Communication Ministries, 2007), 16.

25 Ibid., 16-17.

26 Michael E. Williams, The Storyteller's Companion to the Bible: Genesis (Nashville, TN: Abingdon Press, 1991), 27-28. 
Meski manusia telah diciptakan oleh Allah dengan unsur kemiripan dengan Allah sendiri, tetapi ketidaksempurnaan tetap menjadi bagian di dalam gambarannya. Hal tersebut diduga sebagai celah agar manusia memiliki kebergantungan pada Allah sebagai pencipta. Jika demikian adanya, apakah celah-celah kekurangan diri manusia tetap dikatakan indah?

John Navone dalam Enjoying God's Beauty menyatakan bahwa keindahan yang direpresentasikan oleh setiap individu selama ini-termasuk dalam mendeskripsikan sosok Allah yang Mahaindah-merupakan bagian dari motivasi dan kehendak hati manusia. Tidak ada manusia yang hidup tanpa unsur keindahan di sekelilingnya. ${ }^{27}$ Maka dari itu definisi indah bukanlah suatu hal yang mutlak melainkan buatan manusia. Pernyataan diatas dapat dikatakan bahwa setiap manusia hidup dengan mengusahakan keindahan.

Kebutuhan manusia terhadap keindahan merupakan perasaan mendasar yang menjadi sebuah tuntutan pikiran dan hati manusia itu sendiri. Berdasarkan konsep tersebut, saya mencoba mengkritisi definisi keindahan atau kecantikan yang selama ini terpatri oleh dominasi pemahaman pihak tertentu yang kemudian dianggap sebagai pemahaman global.

Saya mencoba menganalisis alasan penggunaan tata riassebagai salah satu bentuk upaya manusia dalam mengusahakan pengaplikasian keindahan untuk memaksimalkan citra diri mereka menghadapi paradigma "cantik" — pada masyarakat umum perkotaan usia 15 tahun ke atas. Masyarakat umum pun saya batasi pada jenis kelamin perempuan sebagai kaum mayoritas pengguna kosmetik. Melalui beberapa wawancara yang telah saya lakukan pada remaja dan pemuda usia 15 tahun hingga 25 tahun, maka saya mendapati satu konsep dasar yang penting dalam melandasi alasan penggunaan tata rias wajah yaitu, pemahaman diri secara pribadi dalam melihat citra tubuh mereka. Kepada beberapa narasumber yang kepadanya saya lakukan percakapan, ditemukan bahwa setidaknya ada 1-3 poin dalam diri mereka secara fisik yang ingin mereka ubah. Jawaban ini didapati ketika saya menanyakan apakah mereka puas dengan keberadaan fisik diri mereka? Ataukah ada bagian yang ingin mereka ubah atau samarkan?. Mendengar jawaban ini, saya sedikit mendapat pemahaman bahwa sebagian besar dari remaja bahkan pemuda merasakan pentingnya citra tubuh yang baik sehingga mereka membutuhkan sebuah pengakuan sesamanya juga untuk memberi penilaian baik atau tidaknya citra tubuh di dalam keberadaan mereka.

Citra tubuh yang dimaksudkan adalah relativitas kondisi gambaran fisik tubuh yang terlihat secara kasat mata. Citra tubuh

Press, 1999), 9.

John Navone, Enjoying God's Beauty (Collegeville, MN: Liturgical 
sendiri terbangun berdasarkan kesan, pikiran, perasaan, dan opini seseorang tentang tubuhnya. Melalui citra tubuh yang telah terbangun, maka subjek yang bersangkutan akan menampilkan diri berdasar pada persepsi normal, dapat diterima, atau menarik menurut konstruksi sosial masyarakat yang berlaku. ${ }^{28}$ Sebagai manusia yang hidup di dalam konstruksi sosial-masyarakat, citra tubuh adalah bagian penting dari totalitas eksistensi sosial yang mereka miliki. ${ }^{29}$ Melalui pemaparan tersebut maka memang benar adanya bahwa kecantikan (beauty) - menurut Cambridge Advanced Learners Dictionary — selama ini hanya diartikan sebatas sebuah kualitas tertentu untuk memuaskan pandangan umum (the quality of being pleasing, especially to look). ${ }^{30}$ Meskipun definisi kecantikan bagi setiap orang tidak pernah mutlak dan akan selalu berbeda karena dilandaskan pada suatu konstruksi pemikiran yang berlaku di tengah masyarakat, sayangnya definisi ini tetap menciptakan perubahan trend di dalam kehidupan bermasyarakat. Salah satunya adalah dengan tata rias wajah atau yang akrab disebut sebagai makeup. Di dalam mendefinisikan objek atau subjek yang cantik, akan selalu terdapat perspektif pribadi berdasarkan standar tertentu yang telah dibangun dalam mengartikan makna keindahan tersebut. Terdapat format tertentu untuk dapat mengatakan bahwa sesuatu atau seseorang merupakan wujud keindahan. ${ }^{31}$ Hal ini juga dikatakan secara tidak langsung oleh Hans Urs von Balthasar dalam teori theological aesthetic yang dibangunnya. Menurut von Balthasar, yang dikutip oleh John Riches dan Ben Quash, manusia berpikir dalam format tertentu yang terbatas. Manusia pada umumnya berpikir mengenai banyak hal yang didalamnya terkait aspek penilaian atau penghakiman berdasarkan bentuk dari kerangka ideal. Kerangka ideal tersebut terbangun berdasarkan pengalaman hidup yang telah tersusun. ${ }^{32}$

Kerangka berpikir Hans Urs von Balthasar mengadopsi beberapa pemikiran filsuf atau teolog, yang diantaranya adalah Thomas Aquinas. Jika dirunut dari berbagai karya pribadinya, von Balthasar mengusung empat buah tema besar yang salah satunya adalah estetika atau kecantikan..$^{33}$ Klaim terbesar von Balthasar terkait teologi estetika adalah bahwa estetika berhubungan erat dengan kejujuran, kebaikan, dan pewahyuan Kristiani yang mendalam mengenai karya Kristus. Oleh sebab itu, dasar dari klaim

${ }^{28}$ Human Diseases and Conditions Forum, "Body Image."

${ }^{29}$ Bryan S. Turner, The Body and Society, $3^{\text {rd }}$ ed. (Cambridge: Cambridge University Press, 2008), 17-18.

30 "Beauty," in Cambridge Advanced Learner's Dictionary (Cambridge: Cambridge University Press, 2013), 149.

${ }^{31}$ Navone, Enjoying God's Beauty, xiii.

32 John Riches and Ben Quash, "Hans Urs von Balthasar," in The Modern Theologians, ed., David F. Ford, 2 ${ }^{\text {nd }}$ ed. (Malden, MA: Wiley-Blackwell Publishing, 1999), 136-138.

${ }^{33}$ Davies, "The Theological Aesthetics," 132. 
ini adalah sikap tidak mementingkan diri sendiri dalam mewujudkan kecantikan yang sejati. ${ }^{34}$

Klaim von Balthasar kemudian menjadi suatu sudut pandang berpengetahuan yang radikal dan mampu mengubah paradigma. Menurut von Balthasar, hakikat keindahan dan kecantikan sendiri terbagi menjadi dua dan perlu dipisahkan menjadi estetika sekuler dan transendental..$^{35}$ Sederhananya, unsur estetika perlu dibahas dari dua sudut yaitu duniawi dan juga teologis. Meskipun dibedakan, von Balthasar tetap berakar pada pemikiran Aquinas yang mengakar pada kata dasar formosa (Latin: bentuk) dan kemuliaan. Dapat dikatakan bahwa hal fundamental dalam teologi estetika yang diusung oleh von Balthasar adalah pembedaan dari sebuah struktur dan ekspresi pengungkapan sebuah objek. Kategori form atau bentuk memiliki sebuah kaitan yang erat dengan Kristologi yang diusung von Balthasar dan membentuk pandangannya tentang iman Kristen sebagai inkarnasi yang tak sederhana untuk terjelaskan. Form dalam pandangan Balthasar juga selalu dapat menyimbolkan sebuah tanda dan penampilan. Hal yang dimaksud dengan tanda adalah sebuah indikator yang terkait dengan gestalt yang menyiratkan kedalaman dan kepenuhan di dalam diri manusia itu sendiri. ${ }^{36}$ Namun sekali lagi perlu diingat bahwa definisi setiap individu dalam memandang bentuk di dalam dunia yang dijalaninya merupakan produk sejarah. ${ }^{37}$

Meskipun manusia adalah produk sejarah, akan tetapi di dalam diri setiap manusia terkandung sebuah bentuk pancaran kecantikan dari dalam diri masing-masing yang menjadikan kita terlihat indah walau sifatnya tidak kekal. Semua ini terkait dengan unsur kebenaran dan kebaikan dari kedalaman realitas hidup individu. ${ }^{38}$ Secara pribadi saya melihat dari pernyataan von Balthasar bahwa estetika di dalam diri setiap manusia terkait pula dengan pola spiritualitas pribadinya. Bila demikian, maka saya menyetujui bahwa kecantikan merupakan sebuah anugerah yang sifatnya tak dapat dibatasi dan malah mampu membangkitkan sebuah daya pesona. Oleh sebab itu, pantaslah manusia dalam keterbatasannya menjadi serupa keindahannya dengan Allah, karena realita keberadaan spiritualnya memang berasal di dalam koridor penciptaan gambaran dari Allah sendiri.

34 Riches dan Quash, "Hans Urs von Balthasar," 136-138.

35 Davies, "The Theological Aesthetics," 133.

36 Ibid., 134.

37 Victor Counted, "Understanding God Images \& God Concepts: Towards a Pastoral Hermeneutics of the God Attachment Experience," Verbum et Ecclesia Journal, Vol. 36 (2015): 1-14.

${ }^{38}$ Davies, "The Theological Aesthetics," 134-135. 


\section{Teologi dan Fenomena Tata Rias}

Setiap manusia berteologi bahkan di dalam menjalani rutinitas keseharian. Ketika membaca beberapa literatur terkait body image dan estetika-khususnya karya von Balthasar-saya menemukan bahwa gambaran diri manusia tak lepas dari fenomenologi hidup dan laku spiritualitasnya. Hal yang saya maksud sebagai fenomenologi adalah sebuah realita aktualisasi kehidupan manusia yang kemudian menjadi pola dasar perilaku manusia di dalam menjalani keseharian hidupnya. ${ }^{39}$ Dengan kata lain, sebuah ekspresi kehidupan yang ditunjukkan oleh setiap manusia melalui eksistensi dirinya, tak terlepas dari aspek fenomenologi hidup, spiritualitas bahkan pemahaman teologi pribadi yang diusung. Ketika seorang individu bertindak aktif memahami dunia di sekelilingnya sebagai sebuah pengalaman hidup, maka secara otomatis ia akan secara aktif menginterpretasikan dan mencipta makna atas pengalaman tersebut. Maka dari itu, seorang individu dapat memaknai keberadaan dirinya sebagai ciptaan yang berharga dan indah, ataukah sebaliknya.

Selama mencoba meneliti melalui studi pustaka maupun studi lapangan, saya menemukan bahwa terdapat beberapa tokoh filsafat umum maupun teolog yang mencoba membahas mengenai topik estetika dan kaitannya dengan keberadaan manusia. Menurut Gijsbert van den Brink, manusia tercipta dalam keunikan jika diperbandingkan dengan mahluk ciptaan lainnya. Salah satu aspek keunikan terbesar yang tidak kelihatan dari luar adalah kemampuan berkreasi dan menginterpretasi. Manusia mampu berpikir dan mengapresiasi. Berdasarkan hal tersebut, manusia dapat menunjukkan eksistensi dirinya sebagai mahluk bermartabat. ${ }^{40}$ Mengutip Peter L. Berger dan Thomas Luckmann dalam buku berjudul "Barbie Culture" yang ditulis oleh Mary F.Rogers tertulis bahwa tata rias, tren berbusana, dan gaya tertentu menjadi suatu konstruksi sosial atau keyakinan yang diterima secara luas. ${ }^{41}$ Berger dan Luckmann melakukan kritik terhadap konstruksi sosial tersebut, sebab, menurut mereka, konstruksi sosial yang berlaku hanya berasal dari interaksi terus-menerus dan bukan sebuah nilai baku. Konstruksi pemikiran sosial yang berlaku dan dianut oleh masyarakat luas hanyalah sebuah kebiasaan dan didasarkan pada hasrat kepentingan komunitas tertentu agar membuahkan imbalan. Bagi mereka yang hidup dan bergantung pada industri yang

39 Stephen W. LittleJohn, Theories of Human Communication (Jakarta: Salemba Humanika, 2009), 204.

40 Gijsbert van den Brink, "Evolutionary Theory, Human Uniqueness and the Image of God," In die Skriflig/In Luce Verbi, Vol. 46, No. 1 (2012): 2, https://doi.org/10.4102/ids.v46i1.39.

${ }^{41}$ Mary F. Rogers, Barbie Culture (London: SAGE Publications, 1999), $129-130$. 
bersangkutan, konstruksi sosial ini menjadi sebuah sumber keuntungan. Namun bagi masyarakat awam yang tidak menyadarinya, mereka akan terhisab dalam warisan mitos yang mengatakan "white is better" yang disinyalir telah menimbulkan diskriminasi berkepanjangan. ${ }^{42}$ Kesalahpahaman ini perlu segera diluruskan. Perlu adanya paradigma baru terkait hakikat kecantikan manusia.

Manusia adalah objek ego transendental yang berkarya melalui pengalaman. Maka dari itu sangatlah manusiawi jika manusia pada umumnya memiliki dorongan yang besar untuk bereksistensi di dalam lingkup dunia. Wajar ketika manusia mencoba untuk mencipta definisi atas dirinya sendiri. Setiap manusia bertindak sebagai pelaku dari setiap keputusan dan realitas yang diciptakannya. Oleh karena itu manusia sanggup membuat pilihan-pilihan di dalam hidup, termasuk dalam mendefinisikan sekaligus mendeskripsikan dirinya sendiri sebagai individu yang indah atau cantik. Pendapat saya berangkat dari pemaparan von Balthasar bahwa manusia sebagai mahluk sejarah, menciptakan sendiri gambaran dirinya sehingga membentuk pola definisi baru mengenai makna citra dirinya melalui sosok supernatural, yakni Allah. ${ }^{43}$ Setelah membentuk konsep tentang citra diri, kemudian manusia merepresentasikan konsep tersebut dalam suatu koridor berpikir yang paten yang kemudian dipakai untuk membicarakan esensi keberadaan dirinya.

Oleh sebab itu, di dalam proses perjalanan kehidupannya, manusia harus mengetahui dan mampu mendefinisikan dirinya dalam suatu rupa tertentu. Rupa ini yang kemudian dinamakan gambaran diri atau awam disebut ciri-ciri yang khas. Maka, disanalah letak pilihan-pilihan yang menjadikan individu menggenggam kecantikannya yang sejati. Sebab, menurut Balthasar-yang didukung oleh beberapa teori psikologi humanis-manusia di dalam pencarian wujud dirinya dominan bekerja menggunakan sisi kognitifnya. Aspek kognitif tersebutlah yang menghubungkan manusia dengan karakteristik inti yaitu kejujuran, kebaikan dan kedalaman pewahyuan Allah terhadap kesejatian manusia. Ketika manusia sebagai mahluk eksistensial mampu merumuskan suatu bentuk keindahan dirinya dengan menggabungkan kognisi dan karakteristik, maka manusia mampu mengekspresikan diri dalam sebuah identitas yang dapat dilihat sebagai kecantikan sejati.

Dalam satu dekade terakhir, sayangnya manusia dalam merumuskan bentuk keindahan diri, maraknya merasa gagal memaknai gambaran keindahan diri. Menurut Kwok Pui Lan,

42 Ibid., 129-132.

${ }^{43}$ Hans Urs von Balthasar, The Glory of the Lord: A Theological Aesthetics, vol. 1 (San Fancisco, CA: Ignatius Press, 1982), 82-83. 
pemaknaan perempuan terhadap gambar diri mulai bergeser. Dalam hal memaknai keindahan, perempuan dikuasai oleh ekonomi kolonial yang memperbudak tubuh dan mengasosiasikannya dengan gambaran tertentu untuk menguntungkan pihak kapitalis. ${ }^{44}$ Sederhananya, dapat dikatakan dalam rangka memenuhi kepenuhan hasrat akan status sosial tertentu; manusia-khususnya mayoritas perempuan-menjadi tergantung pada produk industri yang dalam hal ini disimbolkan oleh berbagai jenis produk tata rias wajah (kosmetik). Mengadaptasi pemikiran Hans Urs von Balthasar yang telah saya ulas pada halaman-halaman sebelumnya, bahwasanya keberadaan manusia selalu dalam usaha untuk menemukan sebuah ekspresi dalam berbagai varietas bentuk. ${ }^{45} \mathrm{Hal}$ tersebut dapat dikatakan sebagai kewajaran dalam hidup manusia. Dalam pencarian tersebut, manusia selalu berkeinginan untuk menunjukkan keberadaannya di dalam konteks sosial-masyarakat. Namun, sayangnya beberapa orang terkungkung dalam konstruksi pemikiran industrialis yang memandang keindahan secara sempit karena hasrat bereksistensi yang keliru.

Maka dari itu, dalam kesimpulan ini saya mengatakan bahwa sekali pun manusia pada umumnya tidak dapat mengelak dari realita bahwa gambar dan rupa Allah ada di dalam dirinya, akan tetapi gambaran itu tetaplah melekat dalam setiap individu tanpa terkecuali. Sehingga dapat dikatakan meski saat ini keberadaan tata rias sekali pun masih marak dipakai untuk merevisi kekurangan pada wajah (acne scar, oily-blemish skin dll) tetapi marak pula yang menggunakannya sebagaimana yang dikatakan von Balthasar sebagai bagian dari gestalt dirinya sebagaimana yang telah saya tuliskan pada sub bab sebelumnya.

Berdasarkan pengamatan singkat atas cuplikan pemikiran tokoh Hans Urs von Balthasar yang saya tuliskan ini, saya menyimpulkan bahwa sekalipun kehidupan manusia tetap di dalam wujud mahluk rapuh yang dapat dikuasai oleh hasrat yang mendorong adanya pencarian bentuk (form) atas pemaknaan citra dan gambaran dirinya; namun dibalik itu ada sisi positif. Sisi positifnya yakni ketika manusia sebagai individu masih terus mencari bentuk akan gambar diri maka realita aktualisasi kehidupan manusia terhadap keberadaan tata rias tak hanya berbatas pada ketidakpuasan akan penampakan ragawi atau fisik melainkan dapat juga berkembang menjadi aktualisasi akan sisi kognisi individu. Dengan kata lain, keberadaan tata rias tidak pernah menjadi kewajiban setiap individu (meski dalam praktik kehidupan perkotaan,

\footnotetext{
${ }^{44}$ Kwok Pui Lan, Postcolonial Imagination \& Feminist Theology (Louisville, KY: Westminster John Knox Press, 2005), 212.

${ }^{45}$ Larry Chapp, "Revelation," in The Cambridge Companion to Hans Urs von Balthasar, eds., Edward T. Oakes and David Moses (Cambridge: Cambridge University Press, 2004), 11-12.
} 
tata rias wajah menjadi sebuah daya tarik tambahan). Namun, keindahan dan kecantikan tetap bisa hadir tanpa tata rias wajah,misalnya dalam sikap (attitude) dan kebersihan diri. Mungkin juga dalam bentuk fenomena-fenomena kreativitas face art seperti yang sedang marak dilakukan 3 tahun terakhir ini.

Terkait dengan pemikiran bahwa riasan wajah sebagai bagian gambaran diri atau kewajiban seorang manusia terkhusus perempuan, maka saya menyatakan dengan tegas bahwa tata rias bukan merupakan jati diri asali manusia dan bukanlah kewajiban. Tata rias memang menjadi fenomena yang mengikat para remaja putri dan wanita pada umumnya, dan menjadi mungkin juga apabila khalayak ramai akan berpikir bahwa tanpa daya ajaib tata rias, maka keindahan tak terwujud. Akan tetapi sebagai pemakai kosmetik, saya pun merasa bahwa setiap pemakainya memiliki berbagai alasan untuk tetap memakai tata rias dan saya merasa fenomenafenomena yang beredar akhir-akhir ini belum melewati batas wajar.

Lain halnya apabila suatu hari nanti jika tata rias itu mengekang kebebasan pribadi manusia untuk berekspresi dan menjadi diri sendiri yang autentik, maka saya merasa disini lah diperlukan rekonstruksi kognisi serta teologis tentang hakikat manusia yang baik adanya karena segambar dengan Allah Sang Pencipta itu sendiri. Maka dari itu kesimpulan sementara saya atas judul "RIASAN WAJAH SEBAGAI BAGIAN GAMBAR DIRI: Bukan Sekadar Kewajiban atau Hasrat" adalah keberadan tata rias mampu menjadi media pengembangan kreativitas diri individu daripada sekedar hasrat melakukan rekonstruksi keindahan gambar diri. Dengan begitu, konsep tata rias yang berkaitan dengan fungsi estetika menjadi selaras dengan konsep pemikiran von Balthasar yang mengetengahkan hubungan erat estetika dengan kejujuran, kebaikan, dan pewahyuan Kristiani yang mendalam mengenai karya Kristus. Karena memang pada hakikatnya pada masa kini tata rias bukan lagi melulu berkaitan dengan mementingkan diri sendiri dalam mewujudkan kecantikan yang sejati. Akhir kata, bagi saya selama manusia secara general dapat mengingat dan menanamkan sebuah landasan berpikir dalam dirinya bahwa riasan wajah sesungguhnya difungsikan untuk memperlengkapi bukan mengubah, maka keberadan tata rias itu sendiri tidak akan mengingkari keindahan asali setiap manusia selaku pribadi. Demikian pemaparan saya. Terima kasih.

\section{Tentang Penulis}

Irene Chrysantheme Roan Pea (Renne) adalah alumna Sekolah Tinggi Filsafat Theologi Jakarta yang saat ini sedang mengikuti proses bina kader calon pendeta sinode GKI. Hobi menulis puisi dan memiliki minat pada kajian pelayanan pastoral konseling maupun pastoral kerumahsakitan, melalui kunjungan fisik maupun media digital secara umum terkhusus bagi kaum muda-mudi. 


\section{Daftar Pustaka}

Balthasar, Hans Urs von. The Glory of the Lord: A Theological Aesthetics, Vol. 1. San Fancisco, CA: Ignatius Press, 1982.

"Beauty." In Cambridge Advanced Learner's Dictionary. Cambridge: Cambridge University Press, 2013.

Brink, Gijsbert van den. "Evolutionary Theory, Human Uniqueness and the Image of God." In die Skriflig/In Luce Verbis Vol. 46, No. 1 (2012): 1-7, https://doi.org/10.4102/ids.v46i1.39.

Chapp, Larry. "Revelation." In The Cambridge Companion to Hans Urs von Balthasar. Eds., Edward T. Oakes and David Moses. Cambridge: Cambridge University Press, 2004.

Conger, John Janeway, and Nancy L. Galambos. Adolescence and Youth: Psychological Development in a Changing World. New York: Addison-Wesley Educational Publisher, 1997.

Counted, Victor. "Understanding God Images \& God Concepts: Towards a Pastoral Hermeneutics of the God Attachment Experience." Verbum et Ecclesia Journal, Vol. 36 (2015): 1-14.

Culp, Kristine A. Vulnerability and Glory: A Theological Account. Louisville, KY: Westminster John Knox Press, 2010.

Davies, Oliver. "The Theological Aesthetics." In The Cambridge Companion to Hans Urs von Balthasar. Eds., Edward T. Oakes and David Moses. Cambridge: Cambridge University Press, 2004.

Delamar, Penny. The Complete Make-up Artist: Working in Film, Television \& Theatre. London: Macmillan, 1995.

Hestianingsih. "Tren Kecantikan Korea Populer karena Banyak Wanita Malas Pakai Makeup." 10 Oktober 2016. Detik. Diakses 4 Juli 2020. https://wolipop.detik.com/read/2016/10/10/161049/3317 070/\%0A234/tren-kecantikan-korea-populer-karenabanyak-wanita-malas-pakai-makeup.

Human Diseases and Conditions Forum. "Body Image." Diakses 4 Juli 2020. http://www.humanillnesses.com/BehavioralHealth-A-Br/Body-Image.html.

Indriani, Ririn, dan Firsta Nodia. 'Banyak Remaja Pakai 'Makeup' ke Sekolah, Apa Kata Psikolog?” 16 Agustus 2017. Suara. Diakses 4 Juli 2020. https://www.suara.com/lifestyle/2017/08/16/130000/ban yak-remaja-pakai-makeup-ke-sekolah-apa-kata-psikolog.

Irawan, Astari. "Wawancara Oleh Penulis." Purwakarta, Indonesia, 2017.

Karim, Aju Isni, dan Andiyanto. The Make Over: Rahasia Rias Wajah Sempurna. Jakarta: Gramedia, 2005.

Kunjana, Gora. "Industri Kosmetik Nasional Tumbuh 20\%." 2018. Investor. https://investor.id/archive/industri- 
kosmetik-nasional-tumbuh-20.

Kwok Pui Lan. Postcolonial Imagination \& Feminist Theology.

Louisville, KY: Westminster John Knox Press, 2005.

LittleJohn, Stephen W. Theories of Human Communication. Jakarta: Salemba Humanika, 2009.

Navone, John. Enjoying God's Beauty. Collegevile, MN: The Liturgical Press, 1999.

- Toward a Theology of Beanty. Collegevile, MN: Liturgical Press, 1996.

Riches, John, and Ben Quash. "Hans Urs von Balthasar." In The Modern Theologians. Ed., David F. Ford, $2^{\text {nd }}$ ed. Malden, MA: Wiley-Blackwell Publishing, 1999.

Rogers, Mary F. Barbie Culture. London: SAGE Publications, 1999.

Sarwono, Sarlito W. Pengantar Psikologi Umum. Jakarta: Rajawali Press, 2012.

Sirait, Hendra. "Wawancara oleh Penulis." Jakarta, Indonesia, 2017.

Tranggono, Retno Iswari, dan Fatma Latifah. Buku Pegangan Ilmu Pengetahuan Kosmetik. Ed., Joshita Djajadisastra. Jakarta: Gramedia, 2007.

Turner, Bryan S. The Body and Society. $3^{\text {rd }}$ ed. Cambridge: Cambridge University Press, 2008.

Wasitaatmadja, Sjarif M. Penuntun Ilmu Kosmetik Medik. Depok: UI Press, 1997.

Wiersbe, Warren W. The Wiersbe Bible Commentary. Colorado Springs, CO: David C. Cook Communication Ministries, 2007.

Williams, Michael E. The Storyteller's Companion to the Bible: Genesis. Nashville, TN: Abingdon Press, 1991. 